\title{
Keterjaminan Kedudukan Dzaul Arham Dalam Kewarisan Islam Melalui Wasiat Wajibah
}

\author{
Laras Shesa \\ Fakultas Syariah IAIN Curup \\ shesalaras@gmail.com
}

\begin{abstract}
Abstrak
Dzaul arham disinggung bagiannya dalam pembahasan wasiat wajibah. Wasiat wajibah berbeda dengan wasiat biasa. Walaupun batasan bagiannya sama yaitu tidak boleh dari sepertiga. Namun mengenai kedudukannya masih terdapat perbedaan pendapat. Dan menurut penulis walaupun dengan adanya perbedaan pendapat itu sedikit tidaknya bagian dzaul arham itu diperhitungkan. Dalam jurnal ini penulis menggunakan metode penelitian kualitatif subtantif, dengan jenis penelitian library research. Data primernya bersal dari literature kepustakaan, dengan metode analisis deduktif, dari sesuatu yang universal mengarah kearah yang spesifik. Kedudukan dzaul arham memang tidak tersurat dalam al-Quran tapi kedudukanya sudah menjadi ijma para ulama masih diperhitungkan dengan beberapa syarat diantaranya tidak ada ashbabul furudh.Kedua, tidak ada ashabah. Dan terakhir, apabila ashhabul furudh hanya terdiri dari suami atau istri saja, maka ia akan menerima hak warisnya secara fardh, dan sisanya diberikan kepada dzawul arham. Melalui wasiat wajibah dzaul arbam sebagai walidain bagiannya diperhitungkan. Dan penyelesaian wasiat wajibah yang penulis sarankan adalah penyelesaian dari Hasbi AshShiddiqi yaitu dengan jalan menentukan bagian masing-masing ahli waris termasuk penerima wasiat wajibah, menggantikan kedudukan orang tuanya yang telah meninggal sesuai kadar penerimaannya.Memberikan bagian penerimaan penerima wasiat wajibah tersebut sebesar bagian yang seharusnya diterima oleh orangtuanya maksimal sepertiga bagian.Memberikan kelebihan tirkah setelah diambil bagian penerima wasiat wajibah kepada para ahli waris sesuai kadar bagiannya masingmasing. Sehingga dengan jalan ini bagian drawul arham masih sangat diperhitungkan kedudukannya atau bisa terjamin kedudukannya.
\end{abstract}

Kata Kunci: Dzaul Arham, Wasiat Wajibah, Waris

\begin{abstract}
Dzaul Arham mentioned his part in the discussion of the obligatory will. Mandatory wills are different from ordinary testaments. Although the boundaries of the section are the same, they cannot be one third. But regarding its position there are still differences of opinion. And according
\end{abstract}

Al Istinbath : Jurnal Hukum Islam vol. 3, no. 2, 2018

IAIN Curup-Bengkulu | p-issn: 2548-3374; e-issn: 2548-3382

Available online at : http://journal.staincurup.ac.id/index.php/alistinbath 
to the author although with the existence of differences of opinion that little or no part of dzaul arham was taken into account. In this journal the author uses substantive qualitative research methods, with the research type library research. The primary data comes from the literature. With the method of deductive analysis, something universal leads to a specific direction. The position of dzaul arham is indeed not written in the Koran but its position has become the ijma of the ulamas still being calculated with several conditions including no furudh ashhabul. Second, there is no ashabah. And finally, if furudh ashhabul only consists of a husband or wife, then he will receive his inheritance fardh, and the rest will be given to dzawul arham. Through the obligatory dzaul arham testament as though the parts are taken into account. And the completion of the obligatory will that the writer recommends is a settlement from Hasbi Ash-Shiddiqi, namely by determining the part of each heir including the recipient of the obligatory will, replacing the position of his deceased parents according to the level of his acceptance. Providing the recipient of the mandatory will for the portion that should have been received by his parents a maximum of one third of the portion. Giving excess balance after taking the mandatory test taker to the heirs according to the level of their respective parts. So that this way the dzawul arham part is still very calculated, or its position can be guaranteed.

Key Word: Dzaul Arham, Wasiat Wajibah, Inheritance

\section{Pendahuluan}

Diantara sebab beralihnya harta seseorang yang telah meninggal kepada yang masih hidup adalah adanya hubungan silahturahmi atau kekerabatan antara keduanya.Adanya hubungan kekerabatan ditentukan dengan adanya hubungan darah yang ditentukan pada saat adanya kelahiran. ${ }^{1}$ Pada tahap pertama seseorang anak memiliki hubungan kerabatan dengan ibu yang melahirkannya.Hal ini bersifat ilmiah dan tidak ada seorangpun yang membantah hal ini karena anak itu jelas keluar dari rahim ibunya.Hubungan keibuan yang secara alami tadi berlaku semenjak adanya kelahiran di dunia ini.Dengan berlakunya hubungan anak dan ibu yang melahirkannya tadi maka dengan sendirinya terjadi hubungan kekerabatan diantara anak yang dilahirkan ibu itu dan orang-orang lain yang juga dilahirkan oleh ibu itu, baik secara langsung maupun tidak langsung.

Pada tahap selanjutnya seseorang mencari hubungan dengan laki-laki yang menyebabkan ibunya itu hamil dan melahirkan.Apabila dapat dipastikan secara hukum bahwa laki-laki yang menikahi ibunya itu menyebabkan ibunya

${ }^{1}$ Amir Syarifuddin, Hukum Kewarisan Islam, (Jakarta: Kencana, 2012), cet. ke-4, h.177. 
hamil dan melahirkan, maka hubungan kerabat berlaku pula dengan laki-laki itu.Laki-laki itu selanjutnya disebut ayahnya.

Dalam hubungan kekerabatan tersebut di atas yang selanjutnya menjadi faktor utama penentunya yaitu akad nikah yang sah diantara ayah dan ibu.Dengan demikian dapat dikatakan bahwa hubungan kekerabatan berlaku antara seorang anak dengan ayahnya bila anak itu dilahirkan dari hasil perkawinan yang berlaku antara ayah dengan ibu yang melahirkan anak tersebut. ${ }^{2}$ Kalau kelahiran berlaku pada waktu ibu dan ayah masih dalam ikatan pernikahan, maka anak yang lahir itu mempunyai hubungan kerabat dengan ayah itu.Kecuali ayah mengingkari anak tersebut dalam sumpah li'an. Dengan kata lain hubungan kekerabatan itu berdasarkan garis keturunan laki-laki. Lantas bagaimana dengan keturunan dari gairs perempuan?Kekerabatan dari garis keturunan perempuan disebut dengan dzaul arbam.

Secara umum dzaul arham itu adalah orang-orang yang mempunyai hubungan kekerabatan.Dikalangan ulama ahlu Sunnah kata dzaul arham ini dikhususkan penggunaannya dalam kewarisan pada orang-orang yang mempunyai hubungan keturunan yang tidak disebutkan Allah furudnya dalam alquran dan tidak pula pada kelompok orang-orang yang berhak atas sisa harta sebagaimana yang dijelaskan oleh Nabi dengan sunnahnya. ${ }^{3}$

Ahli waris yang berhak atas sisa harta yang dinamakan ashabah itu dinyatakan oleh Nabi yaitu laki-laki yang dihubungkan oleh kepada pewaris melalui jalur laki-laki. Kalaudzaul arbam itu adalah orang yang berhubungan keturunan selain orang yang disebutkan dalam alquran dan selain dari laki-laki melalui garis laki-laki. Tentunya ia adalah melalui perempuan baik ia laki-laki atau perempuan. Dengan demikian secara sederhana dikatakan ahli waris ashabah adalah laki-laki dan dzaul arbam adalah perempuan (atau melalui garis perempuan), yang perinciannya dapat dilihat dalam buku-buku yang membicarakan kewarisan terutama di kalangan Hanafiyah.

Tentang apakah dzaul arham dalam pengertian yang disebutkan diatas berhak menjadi ahli waris dan bagaimana caranya ia dapat menjadi ahli waris merupakan topik perbincangan dikalangan ulama. Segolongan ulama teridir dari Umar, Ali, Abdullah, Ubaidah bin Al-Jarah, Muaz bin Jabal dan Abu Darda' dari kalangan sahabat dan ulama sesudahnya seperti syureih umar bin Abdul Aziz, Atha, Thaus, 'Alqamah, Masruq, Ahmad, dan ahli Kufah berpendapat bahwa dzaul arbam berhak menjadi ahli waris bila tidak terdapat ahli waris furudh dan ashabah atau dalam arti ahli warisnya hanya terdiri dari suami atau istri.

2Beni Ahmad Saebani, Figh Mawaris, (Bandung: Pustaka Setia, 2009), h. 109.

${ }^{3}$ Abdul Aziz Muhammad Azzam dan Abdul Wahhab Sayyed Hawwas, Fiqh Munakahat, (Jakarta: Amzah, 2011), cet. ke-2, h. 127. 
Disamping itu mereka juga berdalil dengan hadits yang diriwayatkan Imam Ahmad dalam rangkaian sanadnya dari Sahal bin Huneif yang mengatakan bahwa seseorang laki-laki membunuh orang dengan panahnya dan orang yang mati itu tidak meninggalkan siapa-siapa kecuali saudara ibunya. Abu Ubaidah mengirim surat kepada Umar tentang hal tersebut. Kemudian Umar berkirim surat kepadanya yang menyatakan bahwa ia pernah mendengar Nabi berkata: waris.”

"Saudara Ibu menjadi ahli waris bagi orang yang tidak memiliki ahli

Golongan kedua teridir dari Zaid bin tsabit dari sahabat yang kemudian diamalkan oleh Malik, al-Awza'I, al-Syafi'I, Abu Tsaur, Daud dan Ibnu Jarir yang berpendapat bahwa dzaul arham tidak berhak menerima warisan.Harta yang ada baik semua atau sisa harta diserahkan ke baitul maal.Sebagaimana dijelaskan sebelumnya bahwa sebagian pengikut Imam al-Syafii seperti Muzanni dan Ibnu Sureij dan begitupula ulama mutakhir dari Syafi'iyah berpendapat bahwa kelebihan harta diberikan kepada dzaul arham setelah diberikan kepada kerabat dalam bentuk radd seandainya baitul maal tidak kredibel. ${ }^{4}$

Selain penjelasan diatas ada juga dalam kewarisan Islam bagian untuk dzaul arbam.Draul arbam disinggung bagian dalam pembahasan wasiat wajibah.Wasiat wajibah berbeda dengan wasiat biasa.Wasiat biasa adalah wasiat yang memang harus disebutkan dan disaksikan serta disepakati oleh seluruh ahli waris.Sedangkan wasiat wajibah adalah wasiat yang tanpa perlu disepakati dan disebutkan wajib dilaksanakan. Walaupun batasan bagiannya sama yaitu tidak boleh dari sepertiga. Namun mengenai kedudukannya masih terdapat perbedaan pendapat.Dan menurut penulis walaupun dengan adanya perbedaan pendapat itu sedikit tidaknya bagian dzaul arbam itu diperhitungkan.

Adapun penelitian terkait pembahasan dzaul arbam melalui wasiat wajibah yang peneliti temui ada beberapa yaitu yang pertama berjudul Penerapan Wasiat Wajibah Menurut Kompilasi Hokum Islam Dalam Kajian Normative Yuridis, di tulis oleh Eko Setiawan dalam jurnal Muslim Heritage Vol.1, No. 2 Desember 2016. Dalam artikelnya eko hanya membahas mengenai wasiat wajibah adalah suatu wasiat yang diperuntukkan kepada ahli waris atau kerabat yang tidak memperoleh bagian harta warisan dari orang yang wafat karena terhalang syara.Wasiat wajibah yang dibahas lebih diperuntukkan kepada ahli waris pengganti. Landasan yang digunakan tentu saja berdasarkan kompilasi hokum islam. Berbeda dengan jurnal yang akan peneliti bahas lebih kepada fiqh mawaris

${ }^{4}$ Suparman Usman dan Yusuf Somawinata, Fiqh Mawaris:Hukum Kewarisan Islam, (Jakarta: Gaya Msedia Pratama, 2002), Cet. Ke-2, h. 21. 
itu sendiri tanpa melihat kajian normative yuriidis, karena memang dalam Kompilasi hokum Islam tidak menyinggung mengenai dz̧aul arbam.

Ada juga sebuah artikel yang ditulis oleh website resmi Kemenag Kabupaten Kerinci yang berjudul Wasiat Wajibah Dalam KHI Dan Persfektif Figh.Artikel ini hanya membahas mengani perbandingan wasiat wajibah yang ada dalam Kompilasi hokum Islam dan figh mawaris.Dimana dalam KHI wasiat wajibah lebih diperuntukkan pada bagian anak angkat atau orangtua angkat, sedangkan wasiat wajibah yang dimau oleh wasiat wajibah ada untuk beberapa golongan yaitu bisa jadi dzaul arham bisa juga karena menggantikan furudh yang lebih dekat.

\section{Pembahasan}

\section{Dzaul Arham}

Arham adalah bentuk jamak dari kata rahmun/rahim, yang asalnya dalam bahasa Arab berarti 'tempat pembentukan/menyimpan janin dalam perut $i b u$ '. Kemudian dikembangkan menjadi 'kerabat', baik datangnya dari pihak ayah ataupun dari pihak ibu.Pengertian ini tentu saja disandarkan karena adanya rahim yang menyatukan asal mereka.Dengan demikian, lafazh rahim tersebut umum digunakan dengan makna kerabat, baik dalam bahasa Arab ataupun dalam istilah syariat Islam.

Adapun yang dimaksud dengan dzawil arham adalah setiap kerabat pewaris yang tidak termasuk ashbabul furudh dan ashabah, misalnya bibi (saudara perempuan ayah atau ibu), paman dari pihak ibu (saudara laki-laki ibu), keponakan laki-laki dari saudara perempuan, cucu laki-laki dari anak perempuan, dan sebagainya.

\section{Pendapat Beberapa Imam tentang Dzawul Arham}

Para imam mujtahid berbeda pendapat dalam masalah hak waris dzawil arham, sama halnya dengan perbedaan pendapat yang terjadi di kalangan para sahabat Rasulullah saw. Dalam hal ini ada dua pendapat: ${ }^{6}$

1. Golongan pertama berpendapat bahwa dqawil arbam atau para kerabat tidak berhak mendapat waris. Mereka mengatakan bahwa bila harta waris tidak ada ashbabul furudh atau ashabah yang mengambilnya, maka harta warisan dilimpahkan kepada baitulmal kaum muslimin untuk disalurkan demi

${ }^{5} \mathrm{Al}$ Hafizh Ibn Hajar Al- Asqalani, Terjemah Bulughul Maram, terj.Moh. Machfuddin aladip, (Semarang: Toha Putra. 2010), h. 479.

${ }^{6}$ Dian Khairul Umam, Fiqih Mawaris, (Bandung: Pustaka Setia, 2006), cet. ke-3, h. 23. 
kepentingan masyarakat Islam pada umumnya. Dengan demikian, tidak dibenarkan jika harta tersebut diberikan kepada drawil arbam. Di antara mereka yang berpendapat demikian ialah Zaid bin Tsabit r.a. dan Ibnu Abbas r.a. dalam sebagian riwayat darinya, dan juga merupakan pendapat dua imam, yaitu Malik dan Syafi'i rahimahumullah.

2. Golongan kedua berpendapat bahwa dzawil arbam (kerabat) berhak mendapat waris, bila tidak ada ashbabul furudh, ataupun ashabah yang menerima harta pewaris. Mereka berpendapat bahwa dzawil arbam lebih berhak untuk menerima harta waris dibandingkan baitulmaal, sebab drawil arbam memiliki kekerabatan dengan pewaris. Pendapat ini merupakan jumhur ulama, di antaranya Umar bin Khathab, Ibnu Mas'ud, dan Ali bin Abi Thalib. Juga merupakan pendapat Imam Abu Hanifah dan Ahmad bin Hambal rahimahumullah.

\section{Cara Pembagian Waris untuk Dzawil Arham}

Di antara ulama fiqh terjadi perbedaan pendapat mengenai tata cara memberikan hak waris kepada para kerabat, dan dalam hal ini terbagi menjadi tiga kelompok pendapat sebagai berikut: ${ }^{7}$

1. Menurut Ahlur-Rahmi

Mengenai cara pembagian hak waris para kerabat, ahlur-rahmi menyatakan bahwa semua kerabat berhak mendapat waris secara rata, tanpa membedakan jauh-dekatnya kekerabatan, dan tanpa membeda-bedakan antara laki-laki dengan perempuan.Misalnya, seseorang wafat dan meninggalkan seorang cucu perempuan keturunan anak perempuan, seorang keponakan perempuan dari saudara perempuan, bibi dari pihak ayah (saudara perempuan ayah), bibi dari pihak ibu (saudara perempuan ibu), dan keponakan laki-laki keturunan saudara laki-laki seibu.Maka dalam hal ini mereka mendapatkan bagian waris secara rata, tanpa melebihkan atau mengurangi salah seorang dari ahli waris yang ada.

Mazhab ini dikenal dengan sebutan ahlur-rahmi disebabkan orang-orang yang menganut pendapat ini tidak mau membedakan antara satu ahli waris dengan ahli waris yang lain dalam hal pembagian, mereka juga tidak menganggap kuat serta lemahnya kekerabatan seseorang. Yang menjadi landasan mereka ialah bahwa seluruh ahli waris menyatu haknya karena adanya ikatan kekerabatan.

Mazhab ini tidak masyhur, bahkan dhaif dan tertolak.Karenanya tidak ada satu pun dari ulama atau para imam mujtahid vang mengakuinya apalagi 438.

${ }^{7}$ Thaha Abul Ela Khalifah, Hukum Waris: Pembagian Warisan Berdasarkan Syariat Islam, h. 
mengikuti pendapat ini dengan alasan telah sangat nyata bertentangan dengan kaidah syar'iyah yang masyhur dalam disiplin ilmu mawarits.

2. Menurut Ahlut-Tanzil

Golongan ini disebut ahlut-tanzil dikarenakan mereka mendudukkan keturunan ahli waris pada kedudukan pokok (induk) ahli waris asalnya.Mereka tidak memperhitungkan ahli waris yang ada (yang masih hidup), tetapi melihat pada yang lebih dekat dari ashbabul furudh dan para ashabahnya. Dengan demikian, mereka akan membagikan hak ahli waris yang ada sesuai dengan bagian ahli waris yang lebih dekat, yakni pokoknya. Inilah pendapat mazhab Imam Ahmad bin Hambal, juga merupakan pendapat para ulama mutakhir dari kalangan Maliki dan Syafi'i.

Perhatikan contoh berikut:

a. Bila seseorang wafat dan meninggalkan cucu perempuan keturunan anak perempuan, keponakan laki-laki keturunan saudara perempuan sekandung, dan keponakan perempuan keturunan saudara laki-laki seayah. Maka keadaan ini dapat dikategorikan sama dengan meninggalkan anak perempuan, saudara perempuan sekandung, dan saudara laki-laki seayah. Oleh karena itu, pembagiannya seperti berikut: ${ }^{8}$

1) Cucu perempuan keturunan anak perempuan mendapat $1 / 2$ bagian

2) Keponakan laki-laki keturunan saudara perempuan sekandung mendapat $1 / 2$ bagian

3) Keponakan perempuan keturunan saudara laki-laki seayah tidak mendapat bagian karena terhalang oleh keponakan laki-laki keturunan saudara perempuan sekandung. Sebab keponakan laki-laki keturunan saudara perempuan sekandung di sini sebagai ashabah, karena itu ia mendapatkan sisanya.

b. Seseorang wafat dan meninggalkan keponakan perempuan keturunan saudara perempuan sekandung, keponakan perempuan keturunan saudara perempuan seayah, keponakan laki-laki keturunan saudara perempuan seibu, dan sepupu perempuan keturunan paman kandung (saudara laki-laki seayah). Kasus ini diibaratkan pewaris meninggalkan saudara perempuan sekandung, saudara perempuan seayah, saudara

${ }^{8}$ Komite Fakultas Syariah Universitas Al-Azhar, Abkamul-Mawaarits fil-Fiqhil-Islami, terj. Addys Aldisar dan H. Fathurrahman, (Jakarta: Senayan Abadi Publishing, 2004), Cet. Pertama, h. 27. 
perempuan seibu, dan paman kandung. Maka pembagiannya adalah sebagai berikut: ${ }^{9}$

1) Keponakan perempuan keturunan saudara perempuan sekandung mendapatkan $1 / 2$ bagian

2) Keponakan perempuan keturunan dari saudara perempuan seayah mendapat $1 / 6$ sebagai penyempurna $2 / 3$

3) Keponakan laki-laki keturunan saudara perempuan seibu mendapatkan $1 / 6$ bagian secara fardh

4) Sepupu perempuan anak dari paman kandung juga mendapatkan 1/6 bagian sebagai ashabah.

Begitulah cara pembagiannya, yakni dengan melihat kepada yang lebih dekat derajat kekerabatannya kepada pewaris yang tergolong ashbabul furudh dan ashabah.Adapun yang dijadikan dalil oleh mazhab ablut-tanzil ini ialah riwayat yang marfu' (sampai sanadnya) kepada Rasulullah saw.. Ketika beliau memberi hak waris kepada seorang bibi (saudara perempuan ayah) dan bibi (saudara perempuan ibu) kebetulan saat itu tidak ada ahli waris lainnya, maka beliau memberi bibi (dari pihak ayah) dengan dua per tiga (2/3) bagian, dan sepertiga lagi diberikannya kepada bibi (dari pihak ibu).

Selain itu, juga berlandaskan fatwa Ibnu Mas'ud r.a. ketika ia menerima pengaduan tentang pembagian waris seseorang yang wafat dan meninggalkan cucu perempuan keturunan anak wanita, dan keponakan perempuan keturunan saudara perempuan sekandung. Maka Ibnu Mas'ud memberikan setengah bagian untuk cucu perempuan dan setengah bagian lainnya untuk keponakan perempuan. Lebih jauh mazhab ini menyatakan bahwa hadits Rasulullah saw. dan keputusan yang dilakukan Ibnu Mas'ud menunjukkan betapa kuatnya pendapat mereka. ${ }^{10}$

Adapun dalih orang-orang yang memperkuat mazhab kedua ini, yang tampak sangat logis, adalah bahwa memberikan hak waris kepada dzawil arham tidak dibenarkan kecuali dengan berlandaskan pada nash-nash umum, yang justru tidak memberikan rincian mengenai besarnya bagian mereka masingmasing dan tidak ada pentarjihan secara jelas. Oleh karena itu, dengan mengembalikan kepada pokoknya, karena memang lebih mendekatkan posisinya kepada pewaris, jauh lebih utama dan bahkan lebih berhak. Sebab, rincian besarnya bagian ashhabul furudh dan para ashabah telah dijelaskan. Maka tidak

${ }^{9}$ Ahmad Azhar Basyir, Hukum Waris, (Yogyakarta: UII Press, 2001), Cet. ke-4, h. 20.

${ }^{10}$ Totok Jumantoro dan Samsul Munir Amin, Kamus Ilmu Ushul Fikih, (Jakarta: Amzah, 2005), Cet. Pertama, h. 68. 
ada jalan lain untuk mengenali dan menuntaskan masalah ini kecuali dengan mengembalikan atau menisbatkannya kepada pokok ahli waris yang lebih dekat kekerabatannya kepada pewaris.

\section{Menurut Ablul Qarabah}

Mazhab ini merupakan pendapat Ali bin Abi Thalib r.a. dan diikuti oleh para ulama mazhab Hanafi. Menurut Ablul Qarabah, hak waris para dzawil arbam ditentukan dengan melihat derajat kekerabatan mereka kepada pewaris. Hal ini, menurut mereka, dilakukan dengan mengqiyaskannya pada hak para ashabah, berarti yang paling berhak diantara mereka (para ashabah) adalah yang paling dekat kepada pewaris dari segi dekat dan kuatnya kekerabatan.

Sebagaimana telah diungkapkan, dalam hal melaksanakan pembagian waris untuk drawil arbam, mazhab ini membaginya secara kelompok. Dalam prakteknya sama seperti membagi hak waris para ashabah, yaitu melihat siapa yang paling dekat hubungan kekerabatannya dengan pewaris, kemudian barulah yang lebih kuat di antara kerabat yang ada. Selain itu, pelaksanaannya tetap mengikuti kaidah umum pembagian waris, yakni bagian laki-laki adalah dua kali bagian wanita.

Di samping itu, mazhab ketiga ini telah mengelompokkan dan membagi dzawil arham menjadi empat golongan, kemudian menjadikan masing-masing golongan mempunyai cabang dan keadaannya. Keempat golongan tersebut adalah: ${ }^{11}$

a. Orang-orang yang bernisbat kepada pewaris, yakni:

1) Cucu dari keturunan anak perempuan, dan seterusnya ke bawah, baik laki-laki ataupun perempuan

2) Cicit dari keturunan cucu perempuan dari keturunan anak laki-laki, dan seterusnya ke bawah, baik laki-laki ataupun perempuan.

b. Orang-orang yang dinisbati kekerabatan oleh pewaris, yakni

1) Kakek yang bukan sahih, dan seterusnya ke atas, seperti ayah dari ibu, ayah dari ayahnya ibu (kakek dari ibu).

2) Nenek yang bukan sahih, dan seterusnya ke atas, seperti ibu dari ayahnya ibu, ibu dari ibu ayahnya ibu.

c. Orang-orang yang bernisbat kepada kedua orang tua pewaris, yakni:

1) Keturunan saudara perempuan sekandung, atau yang seayah, atau yang seibu, baik keturunan laki-laki ataupun perempuan. 
2) Keturunan perempuan dari saudara laki-laki sekandung, atau seayah, seibu, dan seterusnya.

3) Keturunan dari saudara laki-laki seibu dan seterusnya.

d. Orang-orang yang bernisbat kepada kedua kakek pewaris atau kedua nenek pewaris, yakni:

1) Bibi (saudara perempuan ayah) pewaris, baik bibi kandung, seayah, atau seibu. Kemudian paman (saudara laki-laki ibu) pewaris, dan bibi (saudara perempuan ibu), dan paman (saudara ayah) ibu.

2) Seluruh keturunan kelompok diatas.

3) Bibi dari ayah pewaris, baik yang kandung, seayah, ataupun seibu. Juga semua pamannya dan bibinya (paman dan bibi dari ayah). Juga pamannya (saudara ayah) yang seibu (mencakup semua paman dan bibi dari ibu, baik yang kandung maupun yang seayah).

4) Seluruh keturunan kelompok diatas.

5) Paman kakak yang seibu, dan juga paman nenek. Kemudian paman dan bibi, baik dari ayah maupun ibu, dari kakek dan nenek.

6) Seluruh keturunan kelompok diatas.

\section{Perbedaan antara Ahlut-tanzil dengan Ahlul Qarabah}

1. Ahlut-tanzil tidak menyusun secara berurutan kelompok per kelompok, dan tidak pula mendahulukan antara satu dari yang lain. Sedangkan ablul qarabah menyusun secara berurutan dan mendahulukan satu dari yang lain sebagai analogi dari ashabah bi nafsihi.

2. Dasar yang dianggap oleh ahlut-tanzil dalam mendahulukan satu dari yang lain adalah berdasarkan dekatnya keturunan dengan sang ahli waris ashbabul furudh atau ashabah. Sedangkan oleh ablul qarabah yang dijadikan dasar ialah dekatnya dengan kekerabatan, dan bagian anak laki-laki dua kali lipat bagian kaum wanita sebagaimana yang berlaku pula dalam kalangan ahlul ashabah.

\section{Cara Pembagian Waris Menurut Ahlul Qarabah}

Telah dikemukakan bahwa ablul qarabah ini mengelompokkan dan memberikan urutan, dalam pembagian hak waris, dengan mengqiyas pada jalur ashabah. ${ }^{12}$ Dengan demikian, menurut ahlul qarabah, yang pertama kali berhak menerima waris adalah keturunan pewaris (anak, cucu, dan seterusnya). Bila 
mereka tidak ada, maka pokoknya: ayah, kakek, dan seterusnya. Jika tidak ada juga, maka barulah keturunan saudara laki-laki (keponakan).Bila mereka tidak ada, maka barulah keturunan paman (dari pihak ayah dan ibu).Jika tidak ada, maka barulah keturunan mereka yang sederajat dengan mereka, seperti anak perempuan dari paman kandung atau seayah.Dengan demikian, berdasarkan urutan tersebut dapat disimpulkan bahwa kelompok ahli waris yang lebih awal disebutkan dapat menggugurkan kelompok berikutnya.

\section{Syarat-syarat Pemberian Hak Waris bagi Dzawil Arham}

1. Tidak ada ashhabul furudh. Sebab, jika ada ashhabul furudh, mereka tidak sekadar mengambil bagiannya, tetapi sisanya pun akan mereka ambil karena merupakan hak mereka secara radd. Sedangkan kita ketahui bahwa kedudukan ahli waris secara ar-radd dalam penerimaan waris lebih didahulukan dibandingkan dzawil arbam.

2. Tidak ada ashabah. Sebab ashabah akan mengambil seluruh hak waris yang ada, bila ternyata tidak ada ashbabul furudh. Dan bila ada ashbabul furudh, maka para ashababakan menerima sisa harta waris yang ada, setelah diambil hak para ashbabul furudh.

3. Apabila ashhabul furudh hanya terdiri dari suami atau istri saja, maka ia akan menerima hak warisnya secara fardh, dan sisanya diberikan kepada drawil arham. Sebab kedudukan hak suami atau istri secara radd itu sesudah kedudukan dzawil arbam. Dengan demikian, sisa harta waris akan diberikan kepada dzawil arbam.

Apabila drawil arbam (baik laki-laki maupun perempuan) seorang diri menjadi ahli waris, maka ia akan menerima seluruh harta waris. Sedangkan jika dia berbarengan dengan salah satu dari suami atau istri, maka ia akan menerima sisanya. Dan bila bersamaan dengan ahli waris lain, maka pembagiannya sebagai berikut: ${ }^{13}$

1. Mengutamakan dekatnya kekerabatan. Misalnya, pewaris meninggalkan ahli waris cucu perempuan dari keturunan anak perempuan, dengan anak cucu perempuan dari keturunan anak perempuan, maka yang didahulukan adalah cucu perempuan dari anak perempuan. Begitu seterusnya.

2. Apabila ada kesamaan pada kedekatan derajat kekerabatan, maka yang lebih berhak untuk dintamakan adalah yang paling dekat dengan pewaris lewat ashhabul furudh atau ashabah. Misalnya, seseorang wafat dan meninggalkan cucu perempuan dari keturunan anak laki-laki, dan cucu laki-laki dari

${ }^{13}$ Usman, Op.Cit.,h. 184. 
keturunan anak perempuan, maka yang lebih didahulukan adalah cucu perempuan dari keturunan anak laki-laki. Dalam contoh ini, tampak ada kesamaan derajat di antara kedua ahli waris, keduanya memiliki hubungan kekerabatan dengan pewaris sama-sama sebagai cucu. Hanya saja, cucu perempuan keturunan anak laki-laki bernasab kepada pewaris lewat jalur ashbabul furudh, sedangkan cucu laki-laki dari keturunan anak perempuan melalui dzawil arbam.

3. Apabila segi derajat dan kedekatannya kepada pewaris sama, maka haruslah mengutamakan mana yang lebih kuat kedekatan kekerabatannya. Misalnya, seseorang wafat dan meninggalkan anak perempuan dari saudara laki-laki sekandung (yakni keponakan sekandung) dengan anak perempuan dari saudara laki-laki seayah (keponakan bukan sekandung), maka dalam keadaan seperti ini kita harus mengutamakan keponakan kandung, dan berarti seluruh harta waris menjadi haknya. Yang demikian itu disebabkan keponakan kandung lebih kuat kekerabatannya. Begitulah seterusnya.

4. Apabila dalam suatu keadaan terjadi persamaan, maka pembagiannya dilakukan secara merata. Artinya, semua ahli waris dari dzawil arbam berhak menerima bagian. Misalnya, seseorang wafat dan meninggalkan seorang anak perempuan dari anak paman kandung, seorang anak perempuan dari anak paman yang lain (sekandung), dan seorang anak perempuan dari anak paman kandung yang lain. Atau dengan redaksi lain, orang yang wafat ini meninggalkan tiga putri keturunan anak paman kandung. Maka harta warisnya dibagi secara merata di antara mereka, karena ketiganya memiliki derajat yang sama dari segi kekerabatan.

5. Aturan pemberian hak waris terhadap para dzawil arham adalah bagian lakilaki dua kali lipat bagian perempuan, sama seperti dalam pembagian para ashabah untuk anak laki-laki dan anak perempuan, sekalipun dzawil arbam itu keturunan saudara laki-laki atau saudara perempuan seibu.

\section{Wasiat Wajibah}

Wasiat adalah harta yang diberikan oleh seseorang kepada orang lain atau beberapa orang tertentu sesudah kematiannya atau memerdekakan budaknya. Baik dia menjelaskan dengan terus terang dalam teks wasiatnya atau tidak menjelaskannya.Wasiat terkadang digunakan untuk barang yang diwasiatkan dan juga untuk akadnya.Apabila dimaksudkan adalah barangnya berarti mengandung makna menyampaikan karena orang yang berwasiat menghubungkan kebaikan dunia dengan kebaikan akhiratnya.

Apabila makna yang dimaksud adalah al-isha berate adalah akadnya. Sebab hal ini berkaitan dengan rukun dan syaratnya.Al-wajibah menurut bahasa 
adalah keharusan yang tetap. Salah satu dalil yang menunjukkan adanya wasiat wajibah adalah:

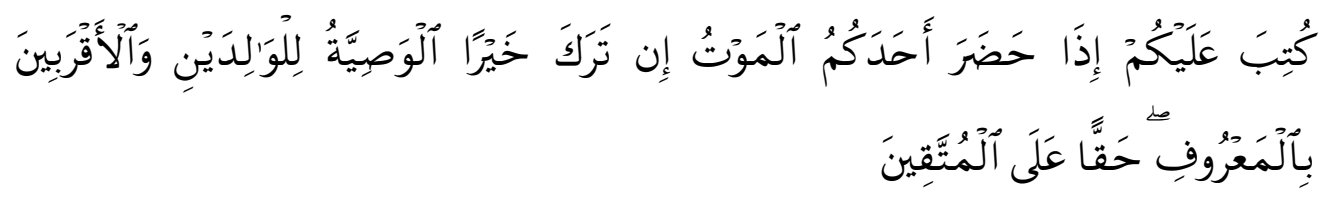

Diwajibkan atas kamu, apabila seorang di antara kamu kedatangan (tanda-tanda) maut, jika ia meninggalkan harta yang banyak, Berwasiat untuk, ibu-bapak dan karib kerabatnya secara ma'ruf, (ini adalab) kewajiban atas orang-orang yang bertakwa.(AlBaqarah: 180).

Pengertian wajib tersimpulkan dari makna ayat diatas pada permulaan ayat ini yaitu kutiba yang artinya diwajibkan dan di penghujung ayat yaitu haqqan 'alal mutaqqin, sebagai kewajiban atas orang-orang yang bertaqwa.

Hikmah berwasiat untuk selain ahli waris terlihat jelas dalam beberapa kondisi yang mengharuskan seseorang bersilahturahim dengan kerabat, berbuat kebajikan kepada sebagian kerabat, sebab mereka tidak disebutkan haknya oleh ayat mawaris.Dan selain mereka dari kalangan ahli waris menghalanginya.Hal ini termasuk suatu jenis jaminan social keluarga yang umum diluar batasan kewarisan.Oleh karena itu disebutkan sebagai suatu kebajikan dan sikap yang taqwa.Hal ini tidak menzalimi ahli waris, bahkan hak mereka selalu diperhatikan didalamnya.Namun dengan menekankan ketawqaan dalam batasan kewajaran dan keseimbangan dalam memberikan kebajikan dan kemurahan.

\section{Persyaratan Wasiat Wajibah}

1. Hendaknya orang berwasiat belum pernah memberi mereka tanpa imbalan melalui perlakuan lain seperti memberi hibah dalam kadar yang sama dengan wasiat.

2. Mereka bukan termasuk orang yang berhak mendapat sesuatu dari tirkah melalui ashabul furud maupun ashabah.

\section{Orang-Orang Yang Berhak Mendapatkan Wasiat Wajibah}

1. Orang-orang yang tingkat pertama dari keturunan anak perempuan yang orangtua mereka telah mati terlebih dahulu semasa kedua orangtunya atau salah satu dari kedua orangtuanya masih hidup, oleh karena itu tidak berhak mendapat wasiat wajibah ibnu ibnil binti.

2. Keturunan anak dari anak kandung dan seterusnya hingga ke bawah namun dengan syarat setiap orangtua dari mereka menghijab anaknya sendiri, 
namun tidak anak yang lain. Bagian setiap orangtua dibagikan kepada anaknya masing-masing dan seterusnya dengan pembagian warisan.

\section{Kadar Wasiat Wajibah}

Wasiat wajibah mempunyai kadar yang sama dengan apa yang diterima oleh sang anak yang mati di masa orangtuanya masih hidup sebagai warisan dari tirkahnya, sendainyan dia masih hidup disaat kematiannya, akan tetapi dengan syarat tidak melebihi sepertiga. ${ }^{14}$ Jika orang yang mewasiatkan sejumlah $1 / 3$ maka dinilai cukup. Jika yang diwasiatkan sesuatupun, maka wasiat wajibah harus ditunaikan berdasarkan kekuatan hukum namun dalam batasan sepertiga.

Jika wasiat wajibah ditentukan lebih dari sepertiga, maka yang dilaksanakan hanyalah dalam batasan sepertiga sedangkan selebihnya berkedudukan sebagai wasiat ikhtiyariah yang pelaksanaannya bergantung kepada persetujuan ahli waris lainnya.

Kita anggap anak yang mati di masa kehidupan orang yang diwarisinya masih hidup, lalu ditetapkan bagiannya dari tirkah dengan syarat tidak lebih dari sepertiga harta dan kita berikan kepad aorang yang berhak menerima wasiat wajibah ini, lalu dibagikan ke mereka dengan ketentuan lidqakrin mitslu hazil unsayain. Adapun sianya dibagikan kepada para ahli waris sesuai dengan bagian ashabul furud atau ashabah masing-masing. Sebagai contoh uraian dibawah ini:

1. Seseorang mati meninggalkan seorang anak laki-laki dan cucu laki-laki pancar laki-laki yang ayahnya telah mati di masa orangtuanya masih hidup, sedangkan tirkahnya berupa lahan seluas 30 hektar.

Penyelesaiannya:

Kita prediksikan anak yang mati saat orangtunya masih hidup dalam keadaan hidup, sehingga tirkahnya dibagi menjadi dua diantara kedua anak laki-laki.Dan sebagaimana yang telah dimaklumi bahwa setengah lebih banyak dari sepertiga, oleh karena itu bagi cucu lelaki dari anak laki-laki berhak mendapat wasiat wajibah dalam batasan sepertiga, tidak boleh lebih dari itu. Kadar wasiat wajibah bagi cucu laki laki dari anak laki-laki ialah:

$30 \times 1 / 3=30 / 3=10$ hektar. Adapun sisany yaitu 20 hektar untuk anak laki-laki yang masih hidup.

2. Seseorang yang mati meninggalkan seorang cucu perempuan dari anak lakilaki yang meninggal dunia saat pewarisnya masih hidup, dua orang anak perempuan, ayah dan nenek dari pihak ibu.

${ }^{14}$ Amir Syarifuddin, Op.cit., h. 247. 
Penyelesaiannya:

Kita prediksikan bagain anak laki-laki jika masih hidup, sehingga dpat ditentukan bagiannya yaitu menjadi ashabah bi ghair bersam dua orang anak perempuan.Sedangkan bagian ayah $1 / 6$ dan nenek dari pihak ibu juga seperenam.Jika ditashihkan maka sisa hartanya 4/6.4/6 dibagikan kepada a' yang berjumlah 4 bagian, sehingga masing-masing mendapat $1 / 6$ untuk dua orang anak perempuan, sedangkan anak laki-laki yang digantikan oleh cucu perempuan pancar laki-laki mendapatkan 2/6.

\section{Keterjaminan Kedudukan Dzaul Arham Dalam Kewarisan Islam Melalui Wasiat Wajibah}

Orang-orang yang berhak menerima wasiat wajibah adalah walidain atau aqrabin yang tidak mendapatkan atau menerima warisan saja, sedangkan mereka yang mendapatkan atau menerima harta peninggalan tidak berhak menerima wasiat wajibah.Mengenai walidai atau aqrabin masih bersifat umum. Hal itu tentu saja menimbulkan pertanyaan apakah setiap walidain atau aqrabin berhak menerima wasiat wajibah.Sebab para walidain tersebut memiliki faktor yang berbeda ketika tiidak bisa menerima warisan. Faktor-faktor yang menyebakannya:

1. Terkena penghalang kewarisan seperti perbudakan, pembunuhan ataupun beda agama.

2. Terkena hijab atau berstatus mahjub.

3. Termasuk dalam golongan dzaul arbam.

Dengan kata lain dari beberapa faktor diatas jika walidain tersebut tergolong sebagai draul arbam maka berhak baginya diberikan wasiat wajibah. Golongan yang menyatakan bahwa dzawul arbam berhak mendapatkan warisan Adalah Ali, Ibnu Mas'ud, Syuraih Al-Qadhi, Ibnu Sirrin, 'Atha, Mujahid Imam Abu hanifah dan Imam Ahmad bin Hambal. Alasan yang dikemukan mereka sebagaiman dikutip oleh Fatcturrahman bahwa rangkaian kalimat "ba'dubum biba'dhin fi kitabillah." Maknanya "ba'dahum aula bimiratsi ba'dhin fima kataballabu wahakam bibi.", yakni sebagian kerabat yang lain menurut ketentuan dan ketetapan Allah. ${ }^{15}$ Bukan berarti bahwa sebagian kerabat itu lebih utama dari pada sebagian kerabat yang lain. Sehingga membawa akibat adanya penafsiran untuk menyisihkan dqaul arbam dari pengertian kerabat secara umum.

Menurut kebanyakan mufassirin ayat 75 Surat Al-Anfal tersebut merupakan penasakh ayat alquran tentang pusaka mempusakai berdasarkan

${ }^{15}$ Usman, Op.Cit.,h. 85. 
ikatan janji prasetia di Surat An-Nisa ayat 33.Karenanya hak waris, para kerabat itu mutlak dan bersifat umum, tidak terbatas kepada kerabat golongan ashbabul furudh dan ashabah saja, melainkan juga golongan draul arbam.Dengan demikian hak waris seluruh kerabat itu harus berdasarkan suatu ketentuan yang bersifat umum yang dalam hal ini sudah tercakup pada kalimat al-arham.

Berdasarkan uraian diatas maka pusaka dzamul arbam ditetapkan oleh alquran bukan menambah hokum yang tidak ditemukan oleh al-quran. Fuqaha Jumhur yang menyatakan adanya hak waris bagi dzaul arham menetapkan dua syarat agar mereka dapat menerima harta peninggalan kerabatnya yang telah meninggal yaitu:

1. Sudah tidak ada ashbabul furudh dan ashabah sama sekali

2. Apabila hanya bersama suami atau istri saja.

Jika hal pertama yang terjadi maka dzaul arhamakan menerima seluruh harta warisan tanpa terkecuali. Jika yang terjadi adalah hal yang kedua maka setelah diambil bagian suami atau istri maka sisanya akan diberikan kepada dzaul arbam. Namun apabila dzaul arbam tersebut lebih dari satu maka ada 3 asas yang bisa mendasari pembagiannya yaitu: ${ }^{16}$ Asas al-Qarabah ialah berdasarkan kedekatan nasab antara draul arbam dengan orang yang meninggal. Draul arbam yang nasab nya lebih dekat akan terlebih dahalu diperhitungkan bagiannya.

Asas tanæil adalah suatu asas dengan menempatkan mereka kepada status ahli waris yang menjadikan sebab adanya pertalian nasab dengan orang yang meninggal dan menggantikan bagiannya, sekiranya ia masih hidup. Jika derajat dzawul arbam tersebut sudah jauh, hendaklah bergeser sederajat demi sederajat sampai mancapai ahli waris mudla bibi yang hendak ditempati kedudukannya.Berhak atau tidaknya dzamul arham ini mendapatkan harta peninggalan tergantung pada mudla bibi yang ditempati kedudukannya.Begitu pula tentang seberapa besar bagiannya tergantung pada mudla bibi yang ditempati kedudukannya.

Asas Rabmi, adalah suatu asas berdasarkan kepada Rahim secara keseluruhan. Karenanya mereka yang ada tatkala meninggalnya si pewaris tidak boleh dibedakan dan tidak boleh diutamakan yang satu dengan yang lainnya. Seluruh ahli waris drawul arbam menurut asas ini berhak mendapatkan bagian yang sama. Jadi apabila drawul arbam yang bakal mewarisi ini beberapa orang maka seluruh harta peninggalan si pewaris dibagi sama rata antar mereka, selama mereka memiliki asas umum yang sama sebagai dzawul arham.

16Ibid.,h. 185. 
Dari pemaparan diatas maka penulis menyarankan penyelesain bagian dzawul arbam tersebut melalui wasiat wajibah dengan penyelesaian menurut Prof. T. M. Hasby Ash-Shiddieqy. Yaitu dengan beberapa jalan yaitu: ${ }^{17}$

1. Menentukan bagian masing-masing ahli waris termasuk penerima wasiat wajibah, menggantikan kedudukan orang tuanya yang telah meninggal sesuai kadar penerimaannya.

2. Memberikan bagian penerimaan penerima wasiat wajibah tersebut sebesar bagian yang seharusnya diterima oleh orangtuanya maksimal sepertiga bagian atau sebesar sepertiga tirkah apabila penerimaannya melebihi batas maksimal tersebut.

3. Memberikan kelebihan tirkah setelah diambil bagian penerima wasiat wajibah kepada para ahli waris sesuai kadar bagiannya masing-masing.

Sehingga dengan jalan ini bagian drawul arbam masih sangat diperhitungkan kedudukannya atau bisa terjamin kedudukannya.Drawul arbam walaupun dengan syarat tertentu daripada tidak sama sekali diperhitungkan kedudukannya padahal bisa jadi kedudukannya lebih dekat dengan si pewaris dan terlebih lagi mungkin lebih membutuhkan dilihat dari faktor usia yang dekat biasanya adalah yang lebih produktif. Sayangnya mengenai dzawul arham sama sekali tidak disinggung bagian dzanul arham di dalam hokum normative yurisdisnya yaitu Kompilasi Hukum islam.

Kompilasi Hukum Islam di Indonesia mempunyai ketentuan tersendiri mengenai konsep wasiat wajibah ini hanya kepada anak angkat dan orang tua angkat saja.Dalam pasal 209 KHI disebutkan bahwa harta peninggalan anak angkat dibagi berdasarkan pasal 176 sampai dengan pasal $193 \mathrm{KHI}$, terhadap orang tua angkat yang tidak menerima wasiat diberikan wasiat wajibah sebanyak sepertiga dari harta warisan anak angkatnya.Sedangkan terhadap anak angkat yang tidak menerima wasiat diberi wasiat wajibah sebanyak-banyaknya sepertiga dari harta warisan orang tua angkatnya.18Berbeda dengan konsep wasiat wajibah yang diatur dalam fiqih yang memberlakukan wasiat wajibah hanya bagi orang yang memiliki hubungan darah dengan si pewaris.Untuk memenuhi kebutuhan dan mengatasi kesulitan yang terjadi ditengah masyarakat maka diberlakukanlah peraturan mengenai hukum wasiat wajibah karena hubungan pengangkatan anak dimasukkan ke dalam Kompilasi Hukum Islam yang merupakan dasar hukum bagi umat Islam di Indonesia.

Dalam undang-undang hukum wasiat Mesir, wasiat wajibah diberikan terbatas kepada cucu pewaris yang orang tuanya telah meninggal dunia lebih

${ }^{17}$ Ibid.,h. 85-86.

${ }^{18}$ Ahmad Rofiq, Op.Cit, h. 110. 
dahulu dan mereka tidak mendapatkan bagian harta warisan disebabkan kedudukannya sebagai dzamil arbam atau terhijab oleh ahli waris lain. ${ }^{19}$ Para ahli hukum Islam mengemukakan bahwa wasiat adalah pemilikan yang didasarkan pada orang yang menyatakan wasiat meninggal dunia dengan jalan kebaikan tanpa menuntut imbalan atau tabarru' .

Sayyid Sabiq mengemukakan bahwa pengertian ini sejalan dengan definisi yang dikemukakan oleh para ahli hukum Islam dikalangan madzhab Hanafi yang mengatakan wasiat adalah tindakan seseorang yang memberikan haknya kepada orang lain untuk memiliki sesuatu baik merupakan kebendaan maupun manfaat secara suka rela tanpa imbalan yang pelaksanaannya ditangguhkan sampai terjadi kematian orang yang menyatakan wasiat tersebut. Sedangkan Al-Jaziri, menjelaskan bahwa dikalangan mazhab Syafi'i, Hambali, dan Maliki memberi definisi wasiat secara rinci, wasiat adalah suatu transaksi yang mengharuskan orang yang menerima wasiat berhak memiliki sepertiga harta peninggalan orang yang menyatakan wasiat setelah ia meninggal dunia.

\section{Penutup}

Kedudukan dzaul arbam memang tidak tersurat dalam al-Quran tapi kedudukanya sudah menjadi ijma para ulama masih diperhitungkan dengan beberapa syarat diantaranya tidak ada ashhabul furudh. Sebab, jika ada ashbabul furudh, mereka tidak sekadar mengambil bagiannya, tetapi sisanya pun akan mereka ambil karena merupakan hak mereka secara radd. Sedangkan kita ketahui bahwa kedudukan ahli waris secara ar-radd dalam penerimaan waris lebih didahulukan dibandingkan drawil arham.Kedua, tidak ada ashabah. Sebab ashabah akan mengambil seluruh hak waris yang ada, bila ternyata tidak ada ashbabul furudh. Dan bila ada ashbabul furudh, maka para ashabahakan menerima sisa harta waris yang ada, setelah diambil hak para ashbabul furudh.Dan terakhir, apabila ashbabul furudh hanya terdiri dari suami atau istri saja, maka ia akan menerima hak warisnya secara fardh, dan sisanya diberikan kepada dqawul arham. Sebab kedudukan hak suami atau istri secara radd itu sesudah kedudukan dzamul arham.Dengan demikian, sisa harta waris akan diberikan kepada drawul arbam.

Melalui wasiat wajibah dzaul arbam sebagai walidain bagiannya diperhitungkan. Dan penyelesaian wasiat wajibah yang penulis sarankan adalah penyelesaian dari Hasbi Ash-Shiddiqi yaitu dengan jalan. Menentukan bagian masing-masing ahli waris termasuk penerima wasiat wajibah, menggantikan kedudukan orang tuanya yang telah meninggal sesuai kadar penerimaannya.Memberikan bagian penerimaan penerima wasiat wajibah

${ }^{19}$ Amir Syarifuddin, Op.Cit, h. 247. 
tersebut sebesar bagian yang seharusnya diterima oleh orangtuanya maksimal sepertiga bagian atau sebesar sepertiga tirkah apabila penerimaannya melebihi batas maksimal tersebut.Memberikan kelebihan tirkah setelah diambil bagian penerima wasiat wajibah kepada para ahli waris sesuai kadar bagiannya masingmasing.

Sehingga dengan jalan ini bagian drawul arbam masih sangat diperhitungkan kedudukannya atau bisa terjamin kedudukannya.Drawul arham walaupun dengan syarat tertentu daripada tidak sama sekali diperhitungkan kedudukannya padahal bisa jadi kedudukannya lebih dekat dengan si pewaris dan terlebih lagi mungkin lebih membutuhkan dilihat dari faktor usia yang dekat biasanya adalah yang lebih produktif. 


\section{Daftar Pustaka}

Ahmad, Beni Saebani, Figh Mawaris, (Bandung: Pustaka Setia, 2013).

Azhar,Ahmad Basyir, Hukum Waris, (Yogyakarta: UII Press, 2014), Cet. ke-7.

Aziz, Abdul Muhammad Azzam dan Abdul Wahhab Sayyed Hawwas, Fiqh Munakahat, (Jakarta: Amzah, 2011).

Hajar, Al Hafizh Ibn Al- Asqalani, Terjemah Bulughul Maram, terj. Moh. Machfuddin aladip, (Semarang: Toha Putra. 2010).

Jumantoro, Totok dan Samsul Munir Amin, Kamus Ilmu Ushul Fikih, (Jakarta: Amzah, 2015), Cet. Ke-5.

Khairul, Dian Umam, Fiqih Mawaris, (Bandung: Pustaka Setia, 2013), cet. ke-5.

Komite Fakultas Syariah Universitas Al-Azhar, Abkamul-Mawaarits fil-FiqhilIslami, terj. Addys Aldisar dan H. Fathurrahman, (Jakarta: Senayan Abadi Publishing, 2004), Cet. Pertama.

Syarifuddin, Amir, Hukum Kewarisan Islam, (Jakarta: Kencana, 2016), cet. ke-7.

Thaha, Abul Ela Khalifah, Hukum Waris: Pembagian Warisan Berdasarkan Syariat Islam. 2012.

Usman,Suparman dan Yusuf Somawinata, Figh Mawaris:Hukum Kewarisan Islam, (Jakarta: Gaya Media Pratama, 2002). 